\title{
Use of GADD45A and CDKN1A Gene Expression Changes as Biomarker in Assessment of DNA Damage for Ionizing Radiation Exposure
}

$$
\text { استخدام التغايرات في التعبير الجيني د جئه الدنا عند التعرض للأشعة الموئية كمؤشر بيولوجي في تقدير الضرر في }
$$

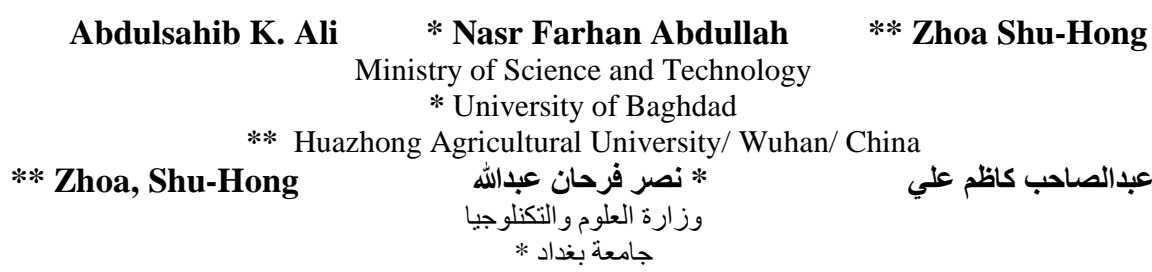

Abstract

The present study aims to determination of GADD45 and CDKN1A expression genes as a biomarkers for ionizing radiation in white mice Mus musculus Balb/C by using the real-time quantitative PCR assay. Seventy- two white mice (36 males and 36 females) were divided into two groups; their whole body was exposed to $5 \mathrm{cGy}$ and $100 \mathrm{cGy}$ of $\mathrm{X}$-ray radiation at a dose rate of $200 \mathrm{cGy} / \mathrm{min}$, in addition to the control group. Total RNA was isolated using Trizol method from liver samples of mice after 6, 48 hours and 10 days of exposure to radiation as well as of the control group. Complementary DNA was used in amplification of genes used in the present study, two types of primers pairs were selected for the genes amplification Growth arrest and DNA-damage inducible A (GADD45A) and Cyclin-dependent kinase inhibitor 1A (CDKN1A), which have a relation with ionizing radiation in addition to the primers for internal control ( $\beta$-actin) gene. The size amplified product were $95 \mathrm{bp}$ and 162 bp nitrogen-base pair for GADD45A and CDKN1A genes, respectively. The existence of significant elevation $p<0.05$ in the amount of gene expression of the GADD45A gene in samples of mice liver exposed to doses 5 cGy and 100 cGy after 6 hours of exposure to radiation. It was found that this gene having up-regulation level after 6 hours in the liver of mice exposed to these doses in comparison with the control group. The presence of a significant reduction $(p<0.05)$ in the amount of gene expression of the CDKN1A gene in samples of mice liver exposed to doses $5 \mathrm{cGy}$ and $100 \mathrm{cGy}$ after 6 hours of exposure to radiation and this reduction continued after 24 hours and 10 days. Moreover, it was found that this gene had a downregulation level after 6 hours in the liver of mice exposed to these doses in comparison with the control group. The organizational level in the high dose of $100 \mathrm{cGy}$ is higher than that at the low dose $5 \mathrm{cGy}$. In conclusion, the results indicated that there is a possibility of using the changes in the level of GADD45A and CDKN1A genes expression as useful biomarkers in assessment of DNA damage for low and high radiation exposure.

Key words: GADD45A, CDKN1A, Biomarker, Ionizing Radiation

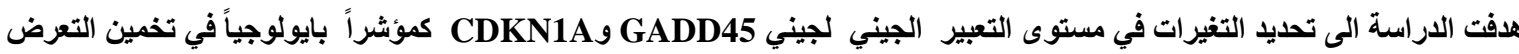

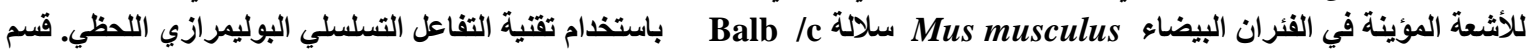

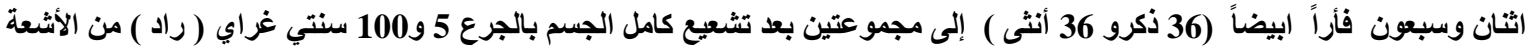

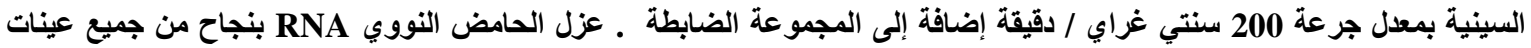

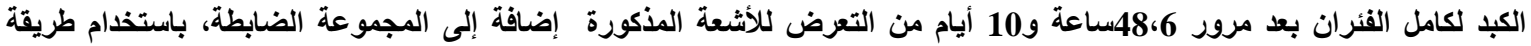
Trizol method

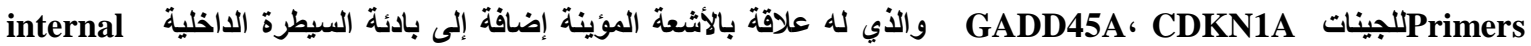
control

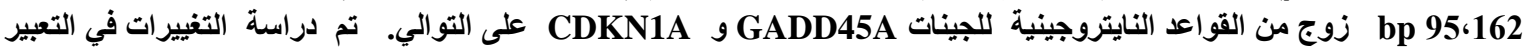

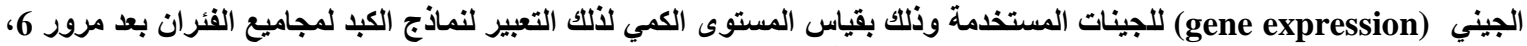

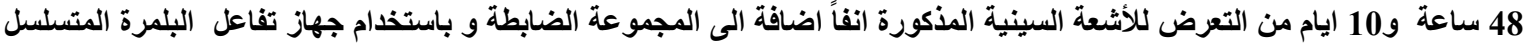
اللحظي QRT-PCR. بينت نتائج الاراسة وجود ارتفاع معنوي 


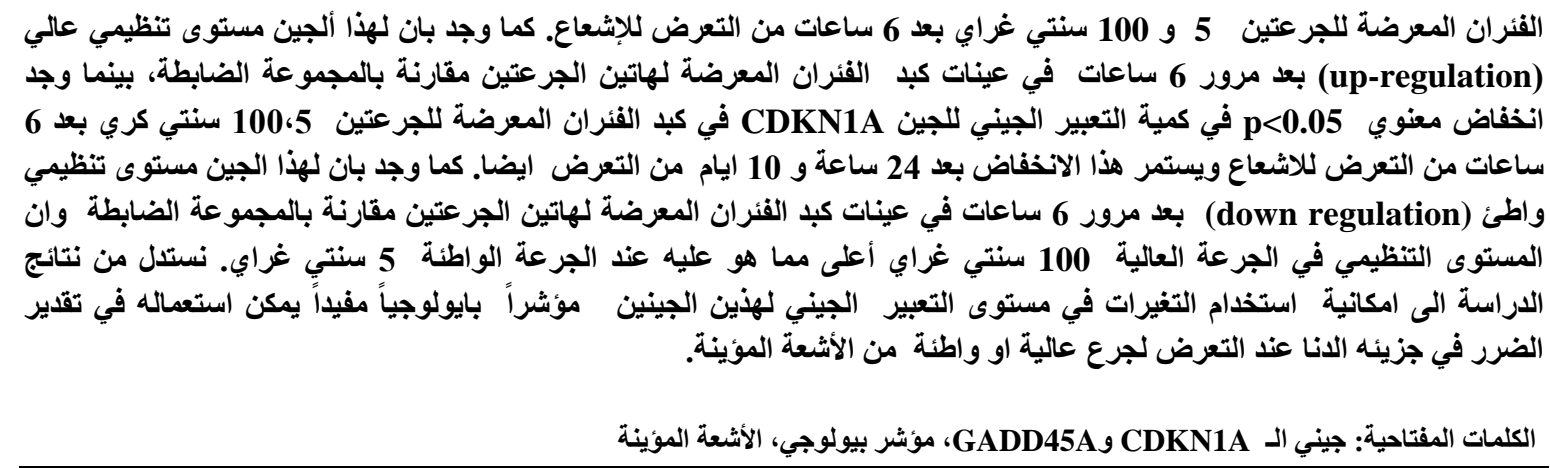

\section{Introduction}

Exposure to ionizing radiation (IR) produces several forms of cellular DNA damage, including single-strand breaks and double-strand breaks $[1,2]$. Thus X-rays can cause DNA and protein damage which may result in organelle failure, block cell division, or cause cell death [3]. Changes in gene expression can affect both the response of cells to radiation exposure, and influence how cells respond to subsequent stimuli [4]. The examination of gene expression after ionizing radiation exposure could serve as a potential molecular marker for biodosimetry. Microarray based studies are identifying new radiation responsive genes that could potentially be used as biomarkers of human exposure to radiation after an accident [5]. Several studies have also shown that gene expression, including expression of many cell cycle-regulated genes, is markedly affected by ionizing radiation, the transcriptional regulation of cell cycle-regulated genes may be closely related to checkpoint functions upon DNA damage. Changes in gene expression may be a mechanism for initiation of cell cycle arrest or a consequence of cell synchronization $[6,7,8,9]$.

P53 regulates the expression of various genes involved in DNA repair, cell cycle progression, and cell death and coordinates these pathways to determine cell fate. Some well-characterized targets of p53 include Growth arrest and DNA-damage-inducible 45A [10]. The expression of GADD45A and CDKN1A are controlled by the tumor suppressor protein $\mathrm{p} 53$, through which this protein mediates the $\mathrm{p} 53$-dependent cell cycle G1 phase arrest in response to a variety of stress stimuli $[11,12]$. The gene expression changes in the radiation biomarker targets CDKN1A, BAX, GADD45A, XRCC4 and DDB2 genes over several days across a broad dose range in both in vivo and ex vivo irradiated human peripheral blood lymphocytes and measured using a quantitative reverse transcriptase polymerase chain reaction assay in whole blood model $[13,14,15]$. The aims of the present study to assess the effect of ionizing radiation on the expression of GADD45A and CDKN1A genes and using the gene expression to the identification of possible candidate as biomarker for whole body radiation exposure.

\section{Materials and Methods}

\section{Experimental Animals}

During September 2007- May 2008 the seventy - two males and females mice Mus musculus were used in the present study, weighting 30-40 gm, ages 4-6 weeks. They were purchased from Lab house of College of Animal Science and Veterinary Medicine, Huazhong Agriculture University, China. Mice were housed in an environmentally room temperature with food and water.

\section{Irradiated Animals}

The mice were divided into 2 groups contain 48 mice (24 males and 24 females) and control contains 24 mice (12 males and 12 females): Group (A): included 24 mice (12 males and 12 females), it was exposed to low dose of X-ray 5 cGy. Group (B): included 24 mice (12 males and 12 females), it was exposed to high dose of X-ray $100 \mathrm{cGy}$. Group (C): included 24 mice were used a controls without irradiation. Group (A) was divided into 3 subgroups. Subgroup (A1): included 8 (4 males and 4 females) mice, the liver was collected after $6 \mathrm{hr}$ of post-irradiation with control group 8 mice (4 males and 4 females). (A2): included 8 (4 males and 4 females) mice, the liver was collected Subgroup after $48 \mathrm{hr}$ of post-irradiation with control group 8 mice (4 males and 4 females). Subgroup (A3): included 8 (4 males and 4 females) mice, the liver was collected after 10 days of post-irradiation with control group 8 mice ( 4 males and 4 females). 
Group (B) was divided into 3 subgroup: Subgroup (B1): included 8 (4 males and 4 females) mice, the liver was collected after $6 \mathrm{hr}$ of post-irradiation with control group 8 mice (4 males and 4 females). Subgroup (B2): included 8 (4 males and 4 females) mice, the liver was collected after $48 \mathrm{hr}$ of post-irradiation with control group 8 mice (4 males and 4 females). Subgroup (B3): included 8 (4 males and 4 females) mice, the liver was collected after 10 days of post-irradiation with control group 8 mice (4 males and 4 females). The whole body of mice was irradiated by X-ray $(6 \mathrm{kV}, 15.5 \mathrm{~mA})$ in Hubei Province Cancer Hospital (Wuhan, China), with an X-ray machine type primus (seminus Co. Ltd., Germany). The dose rate was $200 \mathrm{cGy} / \mathrm{min}$.

\section{Gene expression}

Fresh liver was used for RNA isolation directly after collection. TRIzol (Invitrogen, U.S.A) was used for RNA extraction according to manufacturer's instructions. RNA integrity and concentration were evaluated by agarose gel electrophoresis and DU 640 Nucleic Acid and Protein Analyzer (BACKMAN, U.S.A) respectively. A total of $2 \mu \mathrm{g}$ RNA was used for reverse transcription (RT) with the TransSript First-Strand cDNA Synthesis Super Mix according to the manufacturer's instructions (Beijing TransGen Biotech Co., Ltd., China). All primers were designed by the program Primer and synthesized by the commercial company (Invitrogen). The total volume of PCR reactions was $25 \mu \mathrm{L}$ containing $2.5 \mu \mathrm{L} 10 \times$ Taq buffer, $1.25 \mathrm{U}$ Taq DNA polymerase, $5 \mathrm{mM}$ dNTPs, 50 pmol of each primer and 100ng of template DNA, 1.25 U Taq DNA polymerase, $5 \mathrm{mM}$ dNTPs, 50 pmol of each primer and 100ng of template DNA. PCR reactions were performed on the Mastercycler gradient (eppendorf). PCR thermol program were: $94^{\circ} \mathrm{C}, 5 \mathrm{~min} ; 38 \mathrm{cycles}$ of 30 $\mathrm{s}$ at $94^{\circ} \mathrm{C}, 30 \mathrm{~s}$ at each $\mathrm{Ta}(\mathrm{C})^{0}$ as appropriate (Table 1), and many seconds as appropriate $(60 \mathrm{~s} / \mathrm{kb})$ at $72^{\circ} \mathrm{C}$; and $72^{\circ} \mathrm{C}$ for $10 \mathrm{~min}$. The PCR product was analyzed by $1.5 \%$ agarose gel electrophoresis and one band was obtained. All solution use in this study manufacturer's instructions from TaKaRa .

Table (1): Primers sequence and molecular weight used for QPCR validation and additional expression profiling

\begin{tabular}{|c|c|c|c|}
\hline $\begin{array}{c}\text { Gene } \\
\text { Symbol }\end{array}$ & Primer sequence $\left(5^{\prime}-3^{\prime}\right)$ & $\begin{array}{c}\text { Target size } \\
\text { bp }\end{array}$ & $\begin{array}{l}\text { Ta } \\
\mathbf{C}^{0}\end{array}$ \\
\hline GADD45A & $\begin{array}{l}\text { Forward: CAGAGCAGAAGACCGAAAG } \\
\text { Reverse: CACGCCGACCGTAATG }\end{array}$ & 95 & 56 \\
\hline CDKN1A & $\begin{array}{l}\text { Forward:AGGCACCATGTCCAATCC } \\
\text { Reverse: AAGTCAAAGTTCCACCGTTCT }\end{array}$ & 162 & 56 \\
\hline $\begin{array}{l}\text { Housekeepin } \\
\text { ggene( } \beta \text { - } \\
\text { actin)* }\end{array}$ & $\begin{array}{l}\text { Forward: CAGCCTTCCTTCTTGGGTAT } \\
\text { Reverse: TGGCATAGAGGTCTTTACGG }\end{array}$ & 100 & 60 \\
\hline
\end{tabular}

* $\beta$-actin was used as loading internal control

QPCR was performed using the IQ ${ }^{\mathrm{TM}} 5$ Real Time PCR Detection System (Bio-Rad) using SYBR ${ }^{\circledR}$ Green Realtime PCR Master Mix (TOYOBO CO., LTD, Japan) as the readout. The QRT-PCR amplification conditions were: $95^{\circ} \mathrm{C}, 3 \mathrm{~min} ; 95^{\circ} \mathrm{C}, 30 \mathrm{sec}, 55-60^{\circ} \mathrm{C}$ as appropriate, $30 \mathrm{sec}$ and $72^{\circ} \mathrm{C}, 15 \mathrm{sec}$ for 40 cycles. Melt curves were obtained by increasing the temperature from $56^{\circ} \mathrm{C}$ to $95^{\circ} \mathrm{C}$ at $0.5^{\circ} \mathrm{C} / \mathrm{sec}$ for $10 \mathrm{sec}$, then cooling at $25^{\circ} \mathrm{C}$ for $30 \mathrm{sec}$. Each primer set amplified a single product as indicated by a single peak present for each gene during melting curve analyses.

Data Analysis and Statistics

The relative quantitative gene expression level was evaluated using the $\Delta \Delta \mathrm{Ct}$ comparative $\mathrm{Ct}$ method. The $\Delta \mathrm{Ct}$ values were calculated by subtracting the RPL32 Ct value for each sample from the target $\mathrm{Ct}$ value of that sample. Fold inductions were calculated using the formula $2^{\wedge}(\Delta \Delta \mathrm{Ct}), \Delta \mathrm{Ct}=$ cycle of threshold, $\Delta \mathrm{Ct}=\mathrm{Ct}$ (housekeeping gene)-Ct (target gene), $\Delta \Delta \mathrm{Ct}=\Delta \mathrm{Ct}$ (treated) $-\Delta \mathrm{Ct}$ (control). Quality of the PCR product was monitored using post-PCR melt curve analysis. The data thus generated can be analyzed by computer software to calculate relative gene expression in samples. A one sample T-test was used to statistically analyze the difference of the derived expression ratios of irradiated versus non-irradiated samples [16].

Results

The amounts of total RNA isolated in this study were ranged between 4.15-12.86, 4.05-11.56 and 4.45$10.43 \mu \mathrm{g}$ per $100 \mathrm{mg}$ mice liver at $6 \mathrm{hr}, 48 \mathrm{hr}$ and 10 days, respectively after exposure to 5 cGy irradiation 
when compared with the control 4.82-12.66 $\mu \mathrm{g}$ per $100 \mathrm{mg}$ mice liver. Whereas the amounts of RNA were 3.77-13.05, 4.60-9.15 and 4.90-11.75 $\mu \mathrm{g}$ per100 mg mice liver at $6 \mathrm{hr}, 48 \mathrm{hr}$ and 10 days, respectively after exposure to $100 \mathrm{cGy}$ irradiation when compared with the control 4.52- $13.46 \mu \mathrm{g}$. Figure (1) illustrates the electrophoretic experiment of the present study in which the integrity of the RNA is evident on $1 \%$ agarose gel electrophoresis where $28 \mathrm{~s}, 18 \mathrm{~s}$ and $5 \mathrm{~s}$ bands are clearly visible, no extra fragments have been observed, and there have been no signs of genomic DNA contamination. As a result, it was judged that most samples were indeed composed of intact RNA and appeared to be comparable in quality. RNA was isolated and reverse transcribed into cDNA by using an anchored oligodT primer and subsequently amplified by PCR. The PCR products were analyzed on $1.5 \%$ agarose gel electrophoresis to detect the absence and presence of band patterns. The amplified cDNA with $\beta$-actin gene was $100 \mathrm{bp}$ in length of all mice liver samples in this study. These results have also shown that there was a single pattern DNA band was clearly visible in each samples, which indicate the DNA and mRNA were undegraded and no primer-dimer formation. In all successful PCR reactions, the $\beta$-actin product $100 \mathrm{bp}$ molecular weight was observed, this considered as a mandatory sign of successful RT reaction upon gel electrophoresis, and its band was located in $100 \mathrm{bp}$ ladder DNA marker that composed of 2000 bp Figure (2).

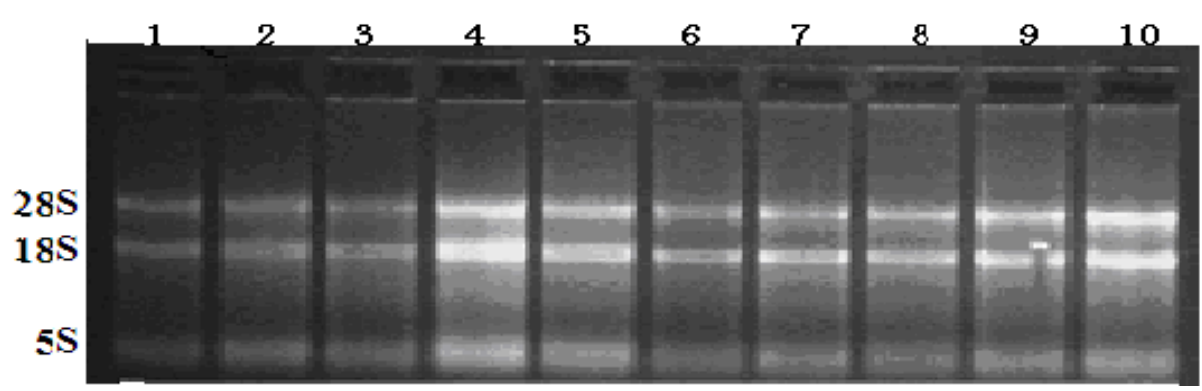

Fig. (1): Agarose gel electrophoresis 1\% of mice liver RNA. Lanes :1- 10 represent partial liver samples

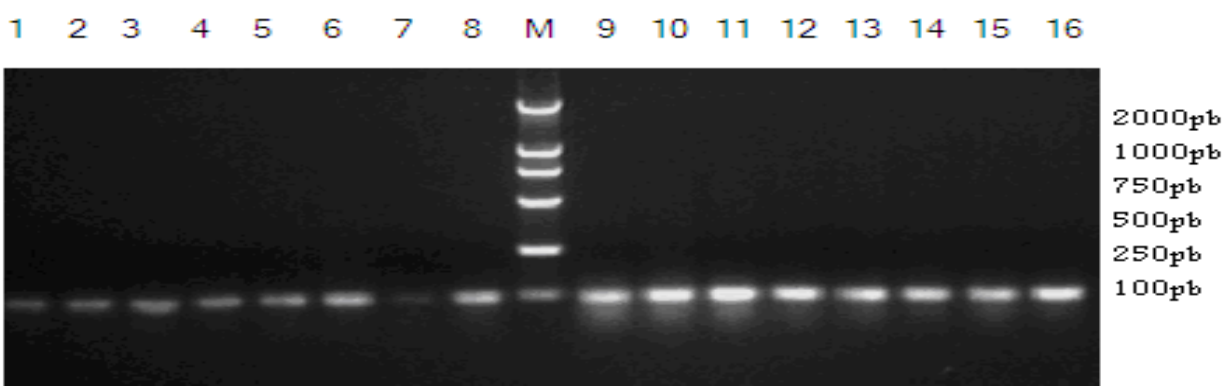

Fig. (2): The size of amplified product of Housckeeping ( $\beta$-actin) genes by $1.5 \%$ agarose gel electrophoresis. The lanes:1-16 represent partial liver samples, M: marker DNA ladder 2000 bp.

A pre-experiment for QRT-PCR, in the present study, showed that the amplified cDNA with $\beta$-actin primer gene was $100 \mathrm{bp}$ in length of all mice liver samples Figure (3). The presence of GADD45A and CDKN1A primer gene was identified, the molecular weight was $95 \mathrm{bp}$ and $162 \mathrm{bp}$, respectively. These results also showed that a single DNA band was clearly visible in each sample, which indicate no primer-dimer formation Figure (3 and 4). Also, as shown in figure (5), the Melt peak chart of these genes in the mice liver after 5 cGy and $100 \mathrm{cGy}$ of whole body x-ray irradiation. Melt curves were obtained by increasing the temperature from $56^{\circ} \mathrm{C}$ to $95^{\circ} \mathrm{C}$ at $0.5^{\circ} \mathrm{C} / \mathrm{sec}$ for $10 \mathrm{sec}$, then cooling at $25^{\circ} \mathrm{C}$ for $30 \mathrm{sec}$. Each primer set amplified a single 
product as indicated by a single peak present for each gene during melting curve analyses.

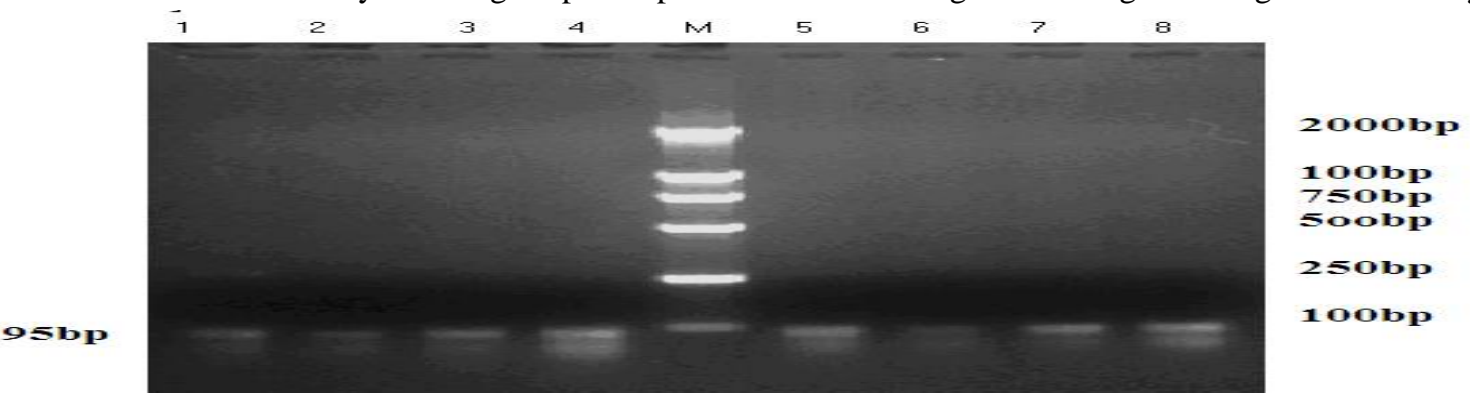

Fig. (3): The size of amplified product of GADD45A gene by $1.5 \%$ agarose gel electrophoresis. Lanes 1-8 represent partial liver samples, $\mathrm{M}$ : marker DNA ladder 2000 bp

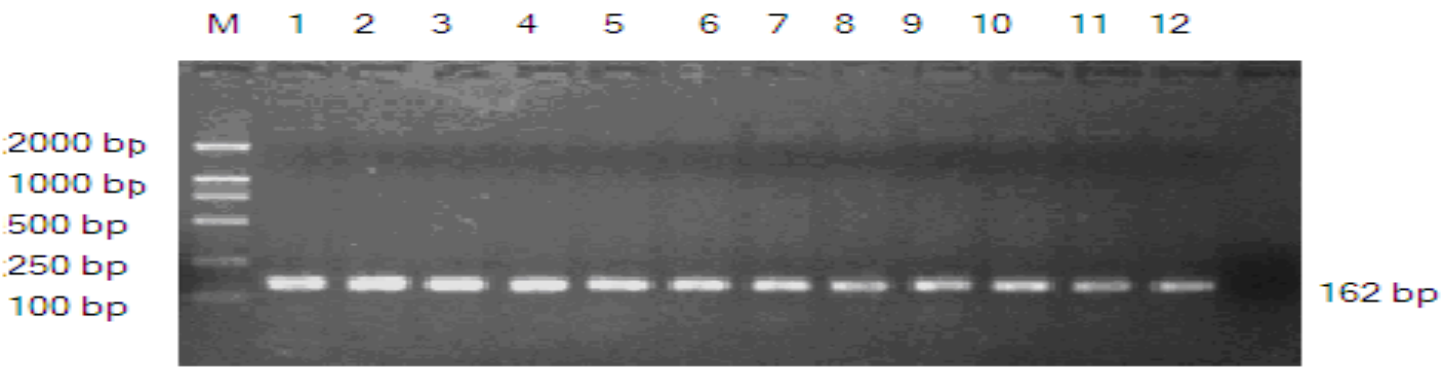

Fig. (4): The size of amplified product of CDKN1A gene by 1.5\% agarose gel electrophoresis. Lanes 1-12 represent partial liver samples, M: marker DNA ladder 2000 bp

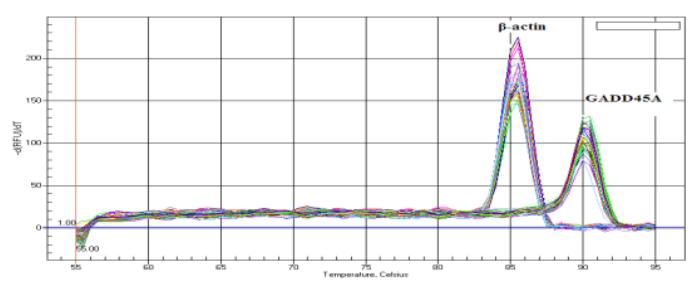

A

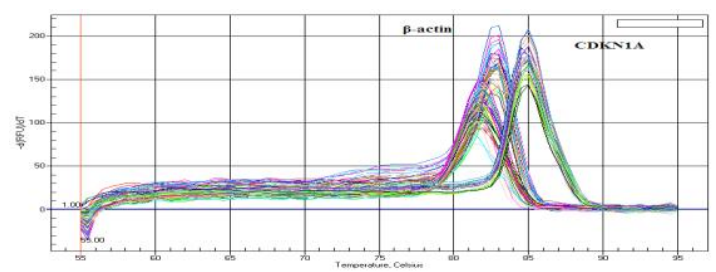

C

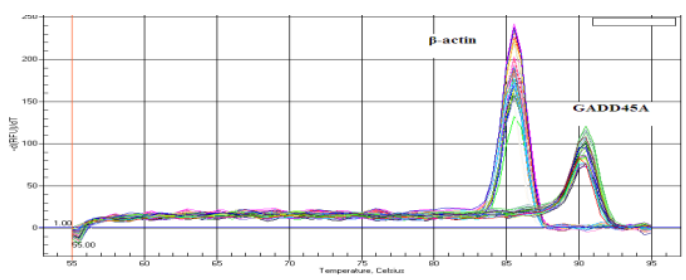

B

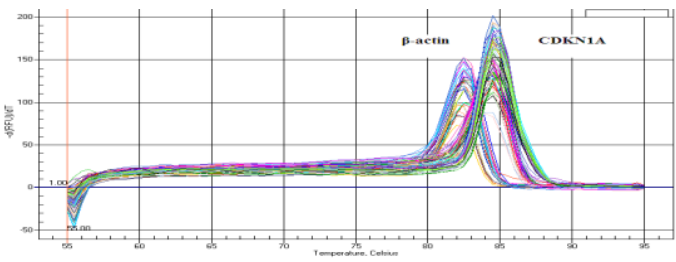

D

Fig. (5): Melt peak of GADD45A( A,B) and CDKN1A( C,D) expression in mice liver at $0 \mathrm{hr}, 6 \mathrm{hr}, 48 \mathrm{hr}$ and 10 days after 5 cGy(A,C) and100 cGy (B,D) of whole body X-ray irradiation. Expression levels of $\beta$-actin are used as the internal control.

The quantitative determination of gene expression biomarkers in mice liver was performed by using Realtime PCR and $\beta$-actin was used as loading controls. The results showed that the relative quantitative gene expression level for three genes GADD45A and CDKN1A in the liver of mice at $0 \mathrm{hr}$ (control), $6 \mathrm{hr}, 48 \mathrm{hr}$ and 10 days after $5 \mathrm{cGy}$ and $100 \mathrm{cGy}$ of whole body X-ray irradiation, which was evaluated using the $\Delta \Delta \mathrm{Ct}$ comparative Ct method Table (2). The quantitative of GADD45A gene expression levels were 59.34, 4.68, 
1.09 , and 23.72 at $6 \mathrm{hr}, 48 \mathrm{hr}$ and 10 days after $5 \mathrm{cGy}$ whole body radiation exposure in mice liver and control respectively. Whereas, the quantitative expression level of this gene was 13.20, 6.17, 3.47 and 5.70 at $6 \mathrm{hr}, 48 \mathrm{hr}$ and 10 days after $100 \mathrm{cGy}$ whole body radiation exposure in mice liver and control respectively. A significant increase $(\mathrm{p}<0.05)$ was observed after the $6 \mathrm{hr}$ of radiation in quantitative gene expression level, compared with $48 \mathrm{hr}, 10$ days and normal non irradiated controls Table (2). Also, the quantitative of CDKN1A gene expression level was 22.83, 1.59, 0.67, and 29.42 at $6 \mathrm{hr}, 48 \mathrm{hr}$ and 10 days after 5 cGy whole body radiation exposure in mice liver and control, respectively. Whereas, the quantitative expression level of this gene was 14.0, 3.89, 1.24 and 30.66 at $6 \mathrm{hr}, 48 \mathrm{hr}$ and 10 days after 100

cGy whole body radiation exposure in mice liver and control, respectively. A significant decrease $(\mathrm{p}<0.05)$ was observed at $6 \mathrm{hr}, 48 \mathrm{hr}$ and 10 days after $5 \mathrm{cGy}$ and $100 \mathrm{cGy}$ of radiation in quantitative gene expression level, as compared with normal non-irradiated controls Table (2).

Table (2): Relative quantitative gene expression levels for GADD45A and CDKN1A in the liver of mice after 5 cGy and 100 cGy of whole body X-ray irradiation using $\Delta \mathrm{Ct}$ method.

\begin{tabular}{|c|c|c|c|c|}
\hline \multirow[b]{2}{*}{$\begin{array}{c}\text { Exposure } \\
\text { times for } \\
\text { X-Rays }\end{array}$} & \multicolumn{2}{|c|}{ Low dose 5 cGy } & \multicolumn{2}{|c|}{ High dose 100 cGy } \\
\hline & $\begin{array}{l}\text { quantitative } \\
\text { GADD45A } \\
\text { expression }\end{array}$ & $\begin{array}{c}\text { quantitative } \\
\text { CDKN1A } \\
\text { expression }\end{array}$ & $\begin{array}{l}\text { quantitative } \\
\text { GADD45A } \\
\text { expression }\end{array}$ & $\begin{array}{c}\text { quantitative } \\
\text { CDKN1A } \\
\text { expression } \\
\end{array}$ \\
\hline O hr & 23.72 B & 29.42 A & $5.70 \mathrm{~B}$ & 30.66 A \\
\hline $6 \mathrm{hr}$ & $59.34 * B$ & 22.83 NS & $13.20 * B$ & $14.00 * \mathrm{~A}$ \\
\hline $48 \mathrm{hr}$ & $4.68 * *$ & $1.59 * \mathrm{~A}$ & 6.17 NS & $3.89 * A$ \\
\hline 10 days & $1.09 * *$ & $0.67 * \mathbf{A}$ & 3.47 NS & $1.24 * \mathrm{~A}$ \\
\hline
\end{tabular}

*A( GADD45A) significant diff.(P<0.05) liver 5 cGy and 100 cGy, Compared with the control; *B ( CDKN1A) significant diff.(P<0.05) liver $5 \mathrm{cGy}$ and $100 \mathrm{cGy}$, Compared with the control; NS= non significant; $* *$ significant diff.

The RT-PCR analysis indicated that the fold expression of GADD45A gene increased significantly $(\mathrm{p}<0.05)$. This was observed at $6 \mathrm{hr}$ after $5 \mathrm{cGy}$ and $100 \mathrm{cGy}$ (32. 88- and 48.13- fold, respectively) in liver of irradiated mice, compared with $48 \mathrm{hr}, 10$ days and normal non irradiated controls. The increase in GADD45A mRNA in liver cell after 100 cGy was higher than that in any cell after 5 cGy Table (3). In this study, the detection of the radiation-responsive CDKN1A performed after whole body radiation of 5 cGy to the liver of mice, the real time -PCR analysis showed that the normalized fold expression of these genes which decreased after $6 \mathrm{hr}$ of radiation and continued to decrease at $48 \mathrm{hr}$ and 10 days. A significant decrease $(\mathrm{p}<0.05)$ was observed after the $6 \mathrm{hr}, 48 \mathrm{hr}$ and 10 days of radiation (13.02-, 2.22-, and 1.00- fold decrease, respectively) in mRNA expression of whole body irradiation, compared with normal non-irradiated controls Table (3). The analysis of expression by real-time PCR in the mice liver also showed significant decreases $(p<0.05)$ in normalized fold expression of the CDKN1A gene at $6 \mathrm{hr}, 48 \mathrm{hr}$ and 10 days after100 cGy whole body irradiation (2.89- , 1.87- and 1.00- fold decrease, respectively) Table (3). 
Table (3): Fold expression levels for GADD45A and CDKN1A gene in the liver of mice after 5 cGy and 100 cGy of whole body X-ray irradiation.

\begin{tabular}{|c|c|c|c|c|c|c|c|c|c|}
\hline \multirow[b]{2}{*}{$\begin{array}{l}\text { Type of } \\
\text { gene }\end{array}$} & \multirow{2}{*}{$\begin{array}{c}\text { Exposure } \\
\text { times for } \\
\text { X-Rays }\end{array}$} & \multicolumn{4}{|c|}{ Low dose 5 cGy } & \multicolumn{4}{|c|}{ High dose 100 cGy } \\
\hline & & $\begin{array}{c}\text { fold } \\
\text { expression }\end{array}$ & $\begin{array}{c}\text { fold } \\
\text { expression } \\
\text { SD } \\
\end{array}$ & $\underset{\mathrm{Ct}}{\text { Mean }}$ & $\begin{array}{l}\text { Ct } \\
\text { SD }\end{array}$ & $\begin{array}{c}\text { fold } \\
\text { expression }\end{array}$ & $\begin{array}{c}\text { fold } \\
\text { expression } \\
\text { SD }\end{array}$ & $\begin{array}{c}\text { Mean } \\
\mathbf{C t}\end{array}$ & Ct SD \\
\hline \multirow{6}{*}{ GADD45A } & O hr & 15.29 a & 12.40 & 23.67 & 0.81 & $4.07 \mathrm{~A}$ & 2.87 & 19.74 & 0.68 \\
\hline & $6 \mathrm{hr}$ & $32.88 * a$ & 42.33 & 23.60 & 1.74 & $48.13 * A$ & 81.34 & 20.06 & 2.30 \\
\hline & $48 \mathrm{hr}$ & 2.88 & 2.67 & 25.72 & 0.80 & $5.45 \mathrm{NS}$ & 6.32 & 19.37 & 1.55 \\
\hline & \multirow[t]{2}{*}{10 days } & & & & & & & & \\
\hline & & 1.00 & 0.79 & 24.82 & 1.02 & 1.00 & 0.81 & 20.03 & 0.95 \\
\hline & 0 hr & $46.60 \mathrm{~b}$ & 18.25 & 20.78 & 0.43 & $6.12 \mathrm{~B}$ & 2.77 & 20.4 & 0.45 \\
\hline \multirow{3}{*}{ CDKN1A } & $6 \mathrm{hr}$ & $13.02 * b$ & 13.15 & 21.09 & 0.44 & $2.89 * B$ & 1.49 & 21.1 & 0.57 \\
\hline & $48 \mathrm{hr}$ & $2.22 * b$ & 1.11 & 21.32 & 0.37 & $1.87 * B$ & 1.23 & 21.3 & 0.82 \\
\hline & 10 days & $1.00 * b$ & 0.35 & 21.12 & 0.46 & $1.00 * B$ & 0.36 & 20.62 & 0.48 \\
\hline
\end{tabular}

*a (GADD45A) significant diff. (P<0.05) liver 5 cGy Compared with the control (a); *A (GADD45A) significant diff. $(\mathbf{P}<0.05)$ liver 100 cGy, Compared with the control (A).*b (CDKN1A) significant diff. (P<0.05) liver 5 cGy, Compared with the control (b); *B (CDKN1A) significant diff. $(\mathbf{P}<0.05)$ liver 100 cGy, Compared with the control (B).Ct=Cycle threshold, $\mathrm{SD}=$ Standard error.
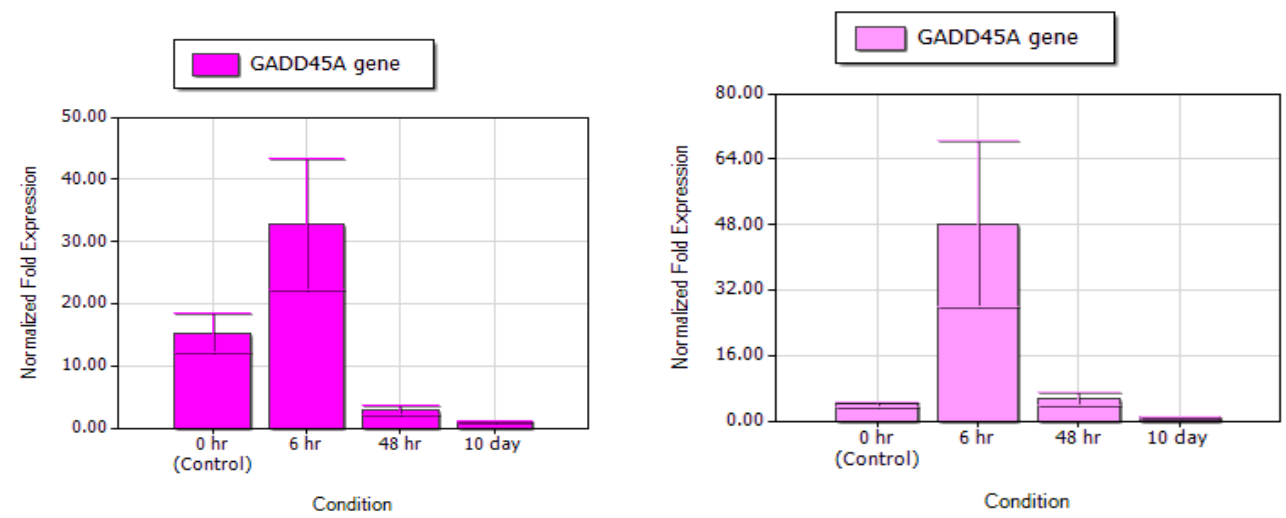

Fig. (6): QRT-PCR graphs showing the relative fold expression levels for GADD45A gene in the liver of mice after 5 cGy (right) and100 cGy (left) of whole body X-ray irradiation.

Also, as shown in Figure (6), the expression of GADD45A gene was up-regulated at the $6 \mathrm{hr}$ after 5 cGy and $100 \mathrm{cGy}$ in liver of irradiated mice, compared with $48 \mathrm{hr}, 10$ days and normal non- irradiated controls. Whereas, the expression of CDKN1A gene has been found to be down regulated at $6 \mathrm{hr}, 48 \mathrm{hr}$ and 10 days after 5 cGy and 100 cGy whole body radiation exposures in mice liver Figure (7). 

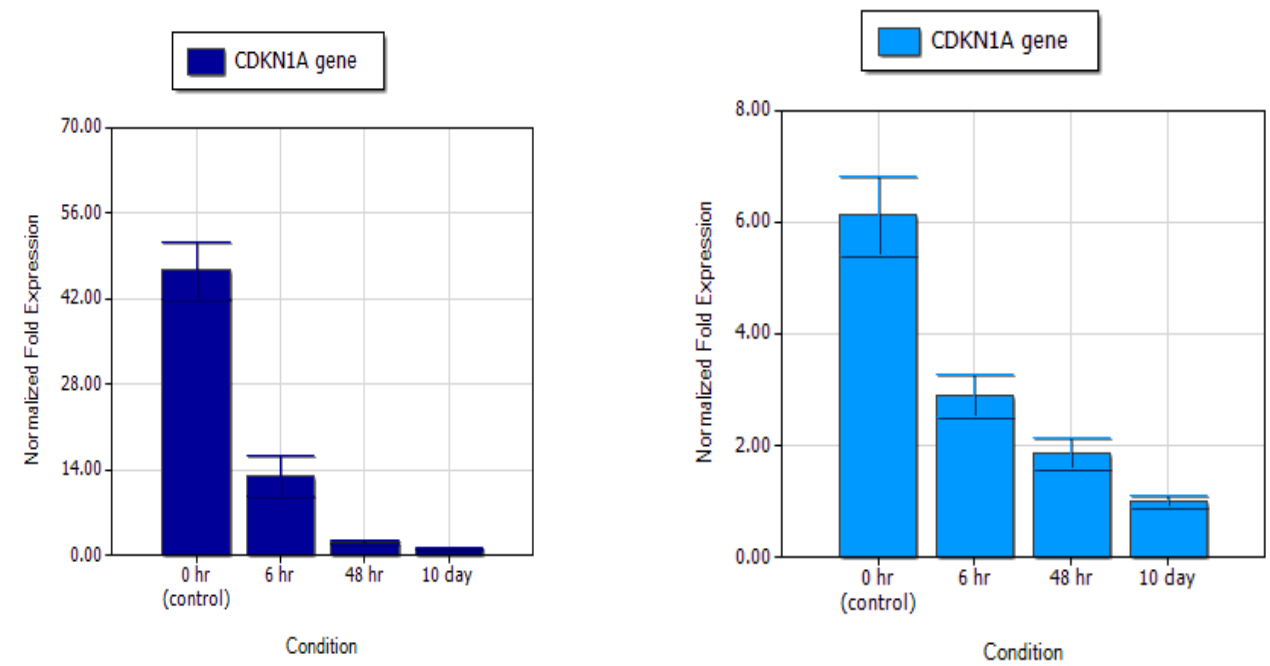

Fig. (7): QRT-PCR graphs showing the relative fold expression levels for CDKN1A gene in the liver of after 5 cGy (right) and100 cGy (left) of whole body X-ray irradiation.

\section{Discussion}

Total RNA has been used as a template for DNA synthesis using reverse transcriptase. Complementary DNA(cDNA) is DNA synthesized from a mature mRNA template in a reaction catalyzed by the enzyme reverse transcriptase, cDNA is often used in gene cloning or as gene probes [17]. Real-time RT-PCR using fluorescence dyes (e.g. SYBR Green I) is currently the most sensitive and precise method for investigation of RNA level and has long been widely used for absolute and relative quantification of mRNA in the cell. Access to RNA requires both cell lysis and inactivation of cellular nucleases during isolation; hence rigorous denaturing lysis conditions are imperative for obtaining intact RNA [18].

In the present study, the RNA has been isolated from liver with a purity ratio ranging from 1.8 to 2.1 in all mice groups. However, in few samples the ratios were slightly lower than that rang below 1.8 between 1.78 1.79. The amount of RNA available for isolation varies with cell types, liver and kidney cells are metabolically active and produce relatively large amounts of RNA per gram of tissue [19]. The results of the current study are similar to those reported by [17] in which the 28s to 18s rRNA 2:1 ratios therefore the (28s:18s) is a good indication of RNA integrity. A pre-experiment for QRT-PCR, in the present study, showed that the amplified cDNA with $\beta$-actin primer gene was $100 \mathrm{bp}$ in length of all mice liver samples. The presence of GADD45A and CDKN1A primer gene was identified the molecular weight was 95 bp and 162 bp, respectively.

The GADD45A gene expression was up-regulated at $6 \mathrm{hr}$ after 5cGy and $100 \mathrm{cGy}$ in liver of irradiated mice, compared with $48 \mathrm{hr}, 10$ days and normal non irradiated controls. The up-regulation occurs when a cell is deficient in some kind of receptor. In this case, more receptor protein is synthesized and transported to the membrane of the cell [20]. In this study, GADD45A was the highest expression at $6 \mathrm{hr}$ after 5 cGy and 100 cGy of X-ray in liver of irradiated mice. Also, it was found up regulated at the same condition in both mice liver. Since of this gene can be regulated by p53 in response to ionizing radiation, so it was suggested that a prominent role for the 53 pathway in the emerging gene expression biomarker signature.

The presence of widely expression levels, GADD45A had the highest expression in liver tissue, which suggests that GADD45A gene expression may be associated with detoxifying tissues [13,21]. However, DNA damage and repair defects that lead to increased tumorogenesis involve multiple factors. Defects in p53, p21, cyclins, or growth suppression genes such as the GADD45 gene family could be involved [22]. Since the liver is a very important metabolic organ in humans, hepatocytes are readily damaged by ionizing radiation. The results of the current study are similar to those reported by [9, 13] in which both GADD45A and GADD45B had the highest expression in liver tissue exposure to ionizing radiation. 
The major transcription factor regulating CDKN1A expression is the tumor suppressor protein p53, these results establish that CDKN1A is not necessary for the acute S-phase damage-sensing pathway that functions to prevent firing of replication origins during $\mathrm{S}$ phase. The expression of CDKN1A gene has been found to be down regulated at $6 \mathrm{hr}, 48 \mathrm{hr}$ and 10 days after $5 \mathrm{cGy}$ and $100 \mathrm{cGy}$ whole body radiation exposures in mice liver. Moreover, the findings of the present study are rather different from those reported previously by[23] who has showed the fold expression of these genes increased after one day of radiation and continued to increase after 3 days. Also, the down-regulation is a process resulting in decreased gene and corresponding protein expression and the expression of the receptor protein is decreased in order to protect the cell [24,25]. The present study has identified candidate biomarkers for radiation exposure that could be detected in liver samples of whole body mice irradiation. This result is similar to those of [23] in which the identification of possible candidate biomarkers for local or whole body $\gamma$ - radiation exposure in C57BL/C mice. These GADD45A and CDKN1A genes are regulated by $\mathrm{p} 53$ in response to ionizing radiation, it was suggested that a prominent role for the p53 pathway in the emerging gene expression biomarker signature. Moreover, the findings of the present study are in agreement with those reported previously by $[15,26]$ who have showed a slight down regulation after exposure to $5 \mathrm{cGy} \mathrm{X}$-radiation. The comparison of gene expression profiles for the $5 \mathrm{cGy}$ and $100 \mathrm{cGy}$ ionizing radiation responsive genes revealed pertinent characteristics of the pathways involved in response to radiation stress. The ionizing radiation responsive genes displayed either an early response to radiation damage within the first $2 \mathrm{~h}$ after ionizing radiation exposure or a late response that has not become apparent until after $6 \mathrm{~h}$ or more following ionizing radiation treatment $[7,15,27]$. The suppression of CDKN1A has led to dysfunction of damage recognition, cell cycle arrest, and apoptosis initiation, all of which are important in carcinogenesis[9].

\section{Conclusions}

The use of quantitative Real-time QRT-PCR in the study of gene expression changes as a biomarker offers rapidity and sensitivity to be applied for the detection of exposure to ionizing radiation. Gene expression study is very important for assessing the effect of ionizing radiation in genomic damage. Although the GADD45A and CDKN1A genes are regulated by $\mathrm{p} 53$ in response to ionizing radiation, the present study has showed that the GADD45A is up-regulation, while the CDKN1A is down-regulation after 6 hours of mice exposure to low and high doses of $\mathrm{x}$-ray and the organizational level in the high dose of $100 \mathrm{cGy}$ is higher than that at the low dose $5 \mathrm{cGy}$.

\section{References}

1. Kastan, M.B. and Kuerbitz, S.J. (1993). Control of G1 arrest after DNA damage. Environ. Health Perspect. 5: 55-58.

2. National Council on Radiation Protection and Measurements NCRP. (2001). Evaluation of the linearnonthreshold dose-response model for ionizing radiation. NCRP Report No. 136.

3. Gutteridge, J. M. and Cross, C.E. (1992). Free radical's antioxidants and human disease. J. Lab. Clin. Med. 119:598-620.

4. Shung, B., Miyakoshi, J. and Takebe, H. (1994). X-ray induced transcriptional activation of C-Myc and XRCC1 genes in ataxia telangiectasia cells. Mutation Research. 307(1):43-51.

5. Chaudhry, A. M. (2008). Biomarkers for human radiation exposure. J. Biomed. Sci. 15:557-563.

6. Bishay, K., Kathy O., Jérôme L., Céline L., Marie-Francoise O. and Chevillard, S. (2000). DNA damagerelated gene expression as biomarkers to assess cellular response after gamma irradiation of a human lymphoblastoid cell line. Oncogene. 19: 916 - 923.

7. Amundson, S.A. and Fornace, A.J. (2001). Gene expression profiles for monitoring radiation exposure. Radiat. Prot. Dosimetry. 97(1):11-16.

8. Jen, K.Y. and Cheung, V.G. (2003).Transcriptional response of lymphoblastoid cells to ionizing radiation. Genome Res. 13:2092-2100.

9. Abdul-sahib, K.A. (2010). Growth Arrest and DNA Damage Inducible 45A (GADD45A) Gene Expression as Biomarkers for Detection of Ionizing Radiation Exposure .Al-kufa University journal for Biology.1(1) :10151027.

10. Huang, L.C.,Clarkin, K.C. and Wahl, G.M. (1996). Sensitivity and selectivity of the DNA damage sensor responsible for activating p53-dependent G1 arrest. Proc. Natl. Acad. Sci. USA. 93: 4827-4832.

11. Liu, Y.,Martindale, J.L., Gorospe, M. and Holbrook, N.J. (1996). Regulation of p21WAF1/CIP1 expression through mitogen activated protein kinase signaling pathway. Cancer Res. 56: 31-35. 
12.Zhan, Q., Antinore, M.J. and Wang, X.W. (1999). Association with Cdc2 and inhibition of Cdc2/Cyclin B1 kinase activity by the p53-regulated protein Gadd45. Oncogene. 18:2892-2900.

13. Grace, M.B., Salter, C.A., Bullard, J.R., Prasanna, P.G.S., Manglapus, G.L. and Blakely, W.F. (2005). GeneExpression biomarkers for application to high-throughput radiation biodosimetry. International Journal of Radiation Biology. 78: 1011-1021.

14. Riballo, E., Kuhne, M., Rief, N., Doherty, A., Smith, G.C., Recio, M.J., Reis, C., Dahm, K., Fricke, A., Krempler, A.,Parker, A.R., Jackson, S.P., Gennery, A., Jeggo, P.A. and Lobrich, M. (2004). A Pathway of double- strand break rejoining dependent upon ATM, artemis, and proteins locating to gamma- H2AX Foci. Mol. Cell. 16(5):715-724.

15. Abdul-sahib, K.A. and N.F. Abdullah. (2010). Cyclin-Dependent Kinase Inhibitor (CDKN1A) Gene Expression as Biomarkers for Detection of Ionizing Radiation Exposure. Tenth Arab Conference on the peaceful uses of Atomic Energy, Republic of Iraq.

16.Vandesompele, J., De Preter, K. and Pattyn, F. (2002). Accurate normal-Ization of real-time quantitative RTPCR data by geometric averaging of multiple internal control genes. Genome Biol. 3(7):1-11.

17.Yan, J., Zhumabayeva, B., Herrler, M. and Premium, B.D. (2002).Total RNA contains virtually no genomic DNA, an important factor in RNA quality. Clone techniques. (4):8-9.

18.Sambrook, J. and Russel, D.W. (2001). Molecular cloning: A laboratory manual. 3rd edition, Cold Spring Harbor laboratory Press, New York.

19.Brisco, P., Sankbeil, J. and Kephart, D. (1997) .Total RNA Isolation System. Technical Manual. Promega PP. 64-67.

20.Hegde, R.S. and Kang, S.W. (2008). The concept of translocation regulation. J. Cell Biol. 182 (2): $225-232$.

21.Weihua, Q., Donald, D., Bingsen, Z., Peiguo, G. C., Zhang, B. and Mengchao, W. (2003). Down-Regulation of Growth Arrest DNA Damage Inducible Gene 45 Expression Is Associated with Human Hepatocellular Carcinoma. American Journal of Pathology. 162(6):1961-1974.

22.Smith,M .L., Ford, M., Hollander, C., Bortnick, A., Amundson, S.A., Seo,Y.R., Deng, C.X., Hanawalt, P.C. and Fornace, A.J. (2000). P53-mediated DNA repair responses to UV radiation: studies of mouse cells lacking p53, p21, and/or gadd45 genes. Mol. Cell Biol. 20:3705-3714.

23.Hae-June, L., Young, G.M., Chang, K., Jeoung,Y.D., Sangwoobe, Z., and Yun, S.L. (2007). Identification of possible candidate biomarkers for local or whole body radiation exposure in C57BL/c mice. Int. J. Radiation Oncology Biol. Phys. 69(4): 1272-1281.

24.Hegde, R.S. and Kang, S.W. (2008).The concept of translocation regulation. J. Cell Biol. 182 (2): $225-232$.

25.Brueckner, F., Armache, K.J. and Cheung, A. (2009). Structure-function studies of the RNA polymerase II elongation complex. Biol. Crystall.ogr. 65: 112-120.

26. Verheyde, J., Saint-Georges, L. D.E., Leyns, L. and Benotmane, M.A. (2006). The Role of Trp53 in the Transcriptional Response to Ionizing Radiation in the Developing Brain. DNA Research. 13: 65-75.

27.Zhao, R., Gish, K., Murphy, M., Yin, Y., Notterman, D., Hoffman, W.H., Tom, E., Mack, D.H. and Levine, A.J. ( 2000). Analysis of p53-regulated gene expression patterns using oligonucleotide arrays. Genes. 14: 981-987. 